\title{
The Implementation of Authentic Award-winning Acceptance Speeches to Enhance IELTS Learners' Motivation in Speaking Skills
}

\author{
Trinh Thi Kieu Dinh \\ Banking Academy of Vietnam, Hanoi, Vietnam
}

\begin{abstract}
Learners' motivation in learning English plays an undeniable role in their progress. However, this is where the problem arises when language teachers find it struggling to boost their motivation to absorb the knowledge and produce a product. Learners' lack of confidence in poor knowledge concerning background and linguistics discourages them from making any noticeable improvements, which is occurring in speaking classes when learners are afraid of voicing their opinions. The implementation of authentic videos to stimulate learners' performance in speaking skills has been widely investigated, still the questions of what and how they are exploited have remained restrictively answered. The study aims at examining the impact of a specific type of video among numerous sources on the speaking ability of five intermediate-level learners who were preparing for the International English Language Testing System (IELTS) examination. The findings revealed that learners were eager to watch the authentic videos and they could learn a great deal from them, especially background knowledge, new range of vocabulary, native pronunciation and intonation.
\end{abstract}

Index Terms-authentic speeches, IELTS speaking skills, motivation

\section{INTRODUCTION}

Teaching Speaking skills has never been easy for language teachers. Albeit various methods proposed and implemented, the real challenge presented to teachers lies in the enhancement of learners' motivation to make progress. The motivation can be derived from external or internal factors exerting influence on students' success. While extrinsic motivation is often ascribed to parents' expectations, friends' pressure, or learners' prior learning experiences, intrinsic motivation, according to Harmer (1991), comes from teachers' teaching methods or physical conditions like the facilities of the class and the learning environment. Among these factors, teachers play an integral part in motivating learners. In other words, their methodology will give students the incentive to stay engaged in the lessons. Thus, all the class activities should be constantly varied to bring in the fresh enjoyment for students. This requires new initiatives to be put in place by making use of authentic materials so that learners' interest can be stimulated and the aims of the lessons will be achieved.

\section{LITERATURE REVIEW}

Speaking is the productive skill in which students must have a good vocabulary range, background and linguistic knowledge to put their thoughts and ideas into words. Yet, students often encounter principal and perennial obstacles like the fear of making pronunciation or grammatical mistakes, the dearth of ideas to express opinions, or the demanding outcomes of the learning program. These difficulties increasingly deter them from speaking confidently in front of the class, which justifies the alternative choices including remaining silent, using the mother tongue, or depending on the dominant speaker in the discussing group or pair. In such situations, teachers must shoulder the responsibility for restoring learners' confidence by providing them with what is necessary to improve this challenging skill.

\section{Authentic materials}

Authentic materials have long been employed in line with the advent of Communicative Language Teaching (CLT) since the 1970s. CLT relieves learners of the pressure to produce linguistically correct speeches as long as they can deliver a message to the audience. To put it another way, the authenticity in which the real-world factors are infused will aid students considerably to gradually overcome their own fears. The role of authenticity in CLT classes by virtue of authentic materials has been accentuated in studies by Nunan (1989), Wesche and Skehan (2002). Authentic materials offer a wealth of real-life expressions as well as social knowledge so that learners can find them extremely valuable in their study. The materials are in the form of a brochure, an advertisement, an article or a video. Students will be exposed to the information concerning the current events and language patterns. As such, they can grasp a deeper understanding of how the language actually works in various contexts.

Authentic videos 
The use of authentic videos has been confirmed in previous studies when they enhance learners' speaking ability tremendously (Rammal, 2006; Yumarnamto and Wibowo, 2008). Stemplesky (2002) claims that the implementation of videos can bring an original and motivating learning experience for learners. Teachers can design a wide variety of activities around the videos for students to discover the language use, the content as well as facial expressions, stimulating them to practice at their own pace. This advantage can be hardly competed by other methods as learners explicitly interact with the video while listening. They can learn substantially from the linguistic expressions, nonverbal communication and viral information. Moreover, the pronunciation and intonation will be favorably impacted since learners no longer have to struggle in their search of appropriate way of speaking. Instead, they will draw inspiration from the native voices to better their own speaking skills, which language teachers have been struggling.

Apart from the merits of authentic videos, choosing the videos tailored to the objectives of the lessons and the needs of the students is what teachers must consider carefully to make the most out of them. Burt (1999) summarized major criteria to decide whether the video selected satisfies the learning requirements. First and foremost, the content must match the learning goals and learners' level at the suitable pace. Moreover, the video should be of learners' interest, which keeps their attention throughout. Likewise, the length of the video is another point worth counting for it should not be too long even though students show deep interest and it will not occupy the time for later analysis and production. In addition, real-life language, which is the target of this teaching technique, may sometimes pose a significant challenge to learners since it is often spoken in different accents and it contains either too formal or too informal expressions.

\section{RESEARCH QUESTIONS}

The research aims at finding the answers to the following questions:

Do authentic award-winning acceptance speeches have influence on language learners' motivation?

What are the effects of authentic award-winning acceptance speeches on learners' motivation?

How can these authentic videos be employed to engage learners in language hours?

\section{Methodology}

IELTS Speaking module tests candidates' ability to communicate in English on daily topics. Accordingly, candidates should give their own ideas and justify them with proper examples without the fear of being right or wrong. However, learners often experience the shortage of appropriate expressions as well as background knowledge, so they do not know how to start the performance and how to organize the ideas. Gradually, when the anxiety keeps growing with no better solutions, they tend to develop a barrier discouraging them from making any progress.

The research employed qualitative methodology to evaluate the influence of authentic videos on learners' motivation to speak English. Five English as a Foreign Language (EFL) learners following an IELTS training course were involved in this project. Their English was at intermediate level and they were not confident in speaking. For them, speaking test or practice was equally difficult, so they were not ready to join activities though they had been applying various methods in their self-study. They were introduced to the authentic videos and required to answer the questions based on the content in the video as well as the related topic. After the lessons, learners were invited to join an interview to elicit their perspectives about the chosen speeches.

The research made use of authentic award-winning acceptance speeches to decide if they can enhance IELTS learners' motivation to improve their speaking skills. Prior researches suggest the use of authentic videos in oral classes after the positive evaluation. Yet, problems as to the type, length or content of the video implemented in language classes stay unconvincingly solved.

Based on one of the five aspects that Scarcella's (2003) detailed, sociolinguistic competence facilitates the ability to compare and contrast, give explanation or justification, describe or define an issue. This works as a paradigm for teachers to infuse the element of authenticity into the classroom but it also ensures that learners are instructed to make use of the authentic videos in the appropriate way.

Three award-winning acceptance speeches were adopted in accordance with the topic and the level of the Speaking lesson. Students were introduced to a film of the concerned topic and required to watch the moment the actor/ actress received the award. While watching, students must work out the organization of the speaker's speeches and classify the collected information into problem-solution, cause-effect, problem-effect, cause-solution, compare-contrast or opinion giving. The ideas were simultaneously added to provide as proof. Teacher then highlighted the linguistic features in the videos so that learners can use in the practice section.

\section{RESULTS}

A. Video 1: Leonardo DiCaprio's 2016 Oscar Acceptance Speech for Best Actor 


\begin{tabular}{|l|l|l|l|}
\hline Movie & Topic & Organization & Ideas \\
\hline The Revenant & Environment & Problem-Solution & $\begin{array}{l}\text { Problem: climate change } \\
\text { Solutions: } \\
\end{array}$ \\
& & $-\begin{array}{c}\text { work together, stop procrastinating } \\
\text { support leaders speaking for indigenous and } \\
\text { underprivileged people mostly affected, for } \\
\text { children's children }\end{array}$ \\
\hline
\end{tabular}

Linguistic features summarized by the teacher:

- "collectively felt"

- "the hottest year in recorded history"

- "climate change is real"

- "the most urgent threat"

- "work collectively together"

- "stop procrastinating"

- “... not speak for the big polluters"

- “... speak for the indigenous people, ... for billions and billions of underprivileged people"

- " "for those whose voices have been drowned out by the politics of greed"

- "let's not take this planet for granted"

B. Video 2: Joaquin Phoenix's 2020 Oscar Acceptance Speech for Best Actor

\begin{tabular}{|c|c|c|c|}
\hline Movie & Topic & Organization & Ideas \\
\hline Joker & Society & Problem - Solution & $\begin{array}{l}\text { Problem: } \\
\text { - "belief that one nation, one people, one race, one } \\
\text { gender, one species, has the right to dominate, use } \\
\text { and control another with impunity" } \\
\text { " we've become very disconnected from the natural } \\
\text { world" } \\
\text { + "Many of us are guilty of an egocentric world view, and } \\
\text { we believe that we're the centre of the universe." } \\
\text { + "We go into the natural world and we plunder it for its } \\
\text { resources." } \\
+ \text { +"We feel entitled to artificially inseminate a cow and steal } \\
\text { her baby, even though her cries of anguish are } \\
\text { unmistakeable." } \\
+ \text { "Then we take her milk that's intended for her calf and } \\
\text { we put it in our coffee and our cereal." } \\
\text { Solutions: } \\
\text { - "use the voice for the voiceless" } \\
\text { - "fight against injustice" } \\
\text { - "human beings at our best are so creative and } \\
\text { inventive, and we can create, develop and implement } \\
\text { systems of change that are beneficial to all sentient } \\
\text { beings and the environment." } \\
\text { "we're at our best: when we support each other. Not } \\
\text { when we cancel each other out for our past mistakes, } \\
\text { but when we help each other to grow. When we } \\
\text { educate each other; when we guide each other to } \\
\text { redemption." }\end{array}$ \\
\hline
\end{tabular}

Linguistic features summarized by the teacher:

- "impunity"

- " "disconnected from the natural world"

- " "guilty of an egocentric world view"

- "centre of the universe"

- "plunder"

- "feel entitled to"

- "her cries of anguish are unmistakeable"

- " "use the voice for the voiceless"

- "implement systems of change"

- "sentient beings"

- " "guide each other to redemption"

C. Video 3: Oprah Winfrey's 2018 Golden Globes 


\begin{tabular}{|c|c|c|c|}
\hline Movie & Topic & Organization & Ideas \\
\hline & Gender & Cause - Effect & $\begin{array}{l}\text { Cause: } \\
\text { - Women abuse in the entertainment industry and } \\
\text { other working areas alike } \\
\text { - Inequality between men and women when women } \\
\text { dare not to tell the truth of being mistreated } \\
\text { Effect: } \\
\text { - Women have risen to reveal the truth and a new } \\
\text { wave of \#metoo has erupted. }\end{array}$ \\
\hline
\end{tabular}

Linguistic features summarized by the teacher:

- "... made history"

- "cheap seats"

- "bone-tired"

- “... women who've inspired me, who've challenged me, who sustained me and made my journey to this stage possible"

- "... who has been the definition of what a friend is"

- “... my rock"

- “... under siege"

- "insatiable dedication"

- " "turning a blind eye to corruption and injustice"

- "navigate these complicated times"

- "transcends any culture..."

- "endure years of abuse and assault"

- "the truth ... goes marching on"

- "a new day is on the horizon"

- “... leaders who take us to the time when nobody has to say me too again"

\section{Discussion Activity}

After the linguistic features were highlighted, teacher raised some questions for further discussion in relation to the topic and the video displayed so that learners could apply the provided resource into the immediate practice. This activity worked as the bridge between theory and practice for learners would not have the feeling of anxiety when asked to perform an activity without prior input of either vocabulary or background knowledge.

For Video 1 (Leonardo DiCaprio's 2016 Oscar Acceptance Speech for Best Actor), teacher required students to discuss in pairs the following questions and encouraged them to refer to the previous lecturing.

Question 1: How serious is climate change?

Student A: Climate change is real and happening at a fast pace. It's hard to find snow now.

Student B: We are collectively feeling hottest years in the recorded history. For example, ice is melting, so Leonardo DiCaprio and his team must move to the tip of the south to find snow for filming The Revenant.

Student C: Climate change is the most urgent threat human beings are facing. Ice is melting.

Question 2: What can humans do to deal with climate change?

Student D: People should work together without procrastinating or delaying actions.

Student E: People should support leaders to fight against climate change for the sake of indigenous people and our children's children.

For Video 2 (Joaquin Phoenix's 2020 Oscar Acceptance Speech for Best Actor), the question and answers were as follows.

Question: What do you think about the relationship between humans and the natural world?

Student A: Humans have been doing things that cause harm to the life of the natural species. They take land for construction. They take the cow for the milk. They take some animals for fur or leather. And this is unacceptable.

Student B: Humans think they are the center of the universe so they can do whatever they like to the natural world. They are doing bad to the Mother Nature and all the species are suffering.

Student C: The relationship between humans and the natural world reflects a bigger picture. Like Joaquin mentioned, in today's world when one gender, one nation or one species can dominate the world with impunity, this is absolutely unfair and must be changed. No one has the right over the others and humans do not have the right over the natural world.

Student D: I think this relationship is getting worse when humans keep doing harm to the environment. Climate change is becoming an urgent threat and the whole world is suffering. That's why humans must change their action now before it's too late.

Student E: The relationship is becoming worse when humans take down trees for wood or take away the animals for their fur or milk or meat. I think the sentient beings must stop thinking they are the dominating species in this world. For Video 3 (Oprah Winfrey's 2018 Golden Globes), the questions and answers were as follows.

Question: How has the role of women changed after the \#metoo movement? 
Student A: \#metoo movement is the definition of the power of women in a world where they are abused and assaulted. Student B: It rocks the world when women refuse to keep secrets and women deserve to have respect.

Student C: It transcends the whole society and makes people rethink the role of women in all aspects like culture, entertainment, labor, etc.

Student D: It has made history with the truth uncovered. Secrets and lies are no longer hidden.

Student E: It signifies a new day on the horizon when people will no longer turn a blind eye to injustice.

From learners' answers, teacher highly evaluated the expressions created when learners could integrate highlighted phrases in their own production and even infuse the concrete evidence into their reasoning. This shows signs of positive impact of the activity on learners' temporary performance.

\section{DISCUSSION}

After the lessons, five students were invited to join the interview session to analyze whether watching such videos motivates them to be confident in speaking skills or not. The interview questions centered around the dominant issues regarding the perspective of learners about the inclusion of authentic videos in class and the influence of such videos on their motivation to speak English.

Question 1: How did you feel after watching those videos?

Five students shared the same feeling that they found inspired by what they had watched. They were all impressed by the way the prize winners articulated their own story.

Student A put it

I am totally carried away by the way Leonardo speaks because it's so real and powerful and I can't take my eyes off him when he is speaking. I totally agree with his view about the effort to save our planet.

Student C claimed that

I have been obsessed with every speech by Oprah Winfrey as she has the ability to awake us by her powerful speech. I love the way she refers to the past and connects it with the present and even the future.

Student D said that

I am absolutely touched by Joaquin's remarks as he is telling the truth that we are refusing to accept. I agree that with love, humans can change the world for the better.

Question 2: Have you watched the films that the actors or actress received the prize? If yes, do you share the same feeling with them? If not, did you watch the film after the lesson?

All the five students had never watched the three movies. However, they all expressed the desire that they would watch them after the lesson because of the impressions these movies had created.

Student A told that

I have been a fan of Oprah Winfrey for years. I love her powerful voice and her powerful thoughts. I have to confess that my hair stands on end when I heard her voice. It really gives me goosebumps as it is so powerful. I will watch it immediately.

Student B expressed that Though I haven't seen the films but I have already known the problems mentioned currently. At first, I didn't want to see them but it is those speeches that make me think again. I am curious about how people fight for their life in a world where injustice is everywhere.

\section{Student D said that}

I have long been a big fan of Leonardo because of his talents. He often puts his true emotions when filming. His thoughts have awakened the whole audience, so I want to see it right away.

Student E shared that

I was really moved by Joaquin's ideas. His thoughts really motivate me to watch it once to see why he was saying like that.

Question 3: What did you learn from those videos with regard to your knowledge and English Speaking skills?

Each student has drawn different knowledge from the videos presented. However, apart from the background knowledge, they unanimously agreed that their English Speaking were improved when they had the motivation to better this skill. From the answers collected, the biggest lesson they can learn is the confidence in speaking. This confidence stems from the correct pronunciation, the attractive intonation, facial expressions, body language and the language use. The issues in the videos and in the films alike are not new, but the way they shared when receiving the prize was literally shaking the world. That was the spotlight moment which students can learn tremendously.

Teachers often struggle to promote learners' motivation to speak English as learners are hesitant to deliver even a small talk or speech in the target language. They do not know how to perform well in terms of pronunciation, intonation, gestures as well as language and background knowledge. The language or the expressions that the speaker used in the videos is so real that learners are really eager to adopt and adapt in their own speech. All these factors contribute to the initial success of a speaking class when the dominant barriers hindering learners' progress are gradually lifted. 


\section{CONCLUSION}

Though the difficulties in speaking English differ from students to students, the lack of motivation to have a confident performance often deters learners from raising their voices. The root of the problem has been identified in numerous researches including the shortage of background knowledge and vocabulary or the fear of making pronunciation mistakes. Meanwhile, the requirements of IELTS Speaking Skills primarily focus on the learners' ability to communicate effectively in various situations, which increases the level of difficulty for learners with low confidence. Thus, helping students overcome those problems and build the confidence to speak is a painstaking journey, which involves more than a single teaching method. The implementation of authentic materials in general and authentic videos in particular has long been introduced in EFL classes. Yet, what type of videos are integrated and how the videos are employed have been under tremendous discussion. This means that teacher must take factors like the needs, level and interest of learners into account for an effective class. In this research, the author made use of short videos recapturing the glamorous moments of different actors or actress receiving the prestigious prize. Their stunning speeches left an impression on the learners and they exerted a favorable influence on learners' motivation to learn from the featured artists and produce short expressions confidently. This paves the way for a succession of follow-up activities designed to enhance learners' motivation and engage them more in language classes.

\section{REFERENCES}

[1] Burt, M. (1999). Using Video with Adult English Language Learners. (www.cal.org/caela/esl_resources/digests/using video with Adult leaner.html accessed on November, 12 2020) Conference on 1-3August 2008. Bali: Indonesia.

[2] Golden Globes 2018: Watch Oprah Winfrey speak on future of women (2018) YouTube video. Available at https://www.youtube.com/watch?v=2yqSMHLL0Oc [Accessed November 12 2020].

[3] Harmer, J. (1991). The practice of English language teaching - Motivational differences. London: Longman.

[4] Joaquin Phoenix wins Best Actor. (2020). YouTube video. Available at https://www.youtube.com/watch?v=qiiWdTz_MNc [Accessed November 12 2020].

[5] Leonardo DiCaprio winning Best Actor. (2016). YouTube video. Available at https://www.youtube.com/watch?v=xpyrefzvTpI [Accessed November 12 2020]

[6] Nunan, D. (1989). Designing Tasks for the Communicative Classroom. Cambridge: Cambridge University Press.

[7] Rammal, S. (2006). Video in EFL Classrooms. http://www.usingenglish.com. retrieved November 152020.

[8] Scarcella, R. (2003). Academic English: A conceptual framework (Technical Report 2003-1). Berkeley, CA: University of California Linguistic Minority Research Institute.

[9] Stempleski, S. (2002). Video in the ELT Classroom: The Role of the Teacher. In J. C. Richards, \& W. A. Renandya (Eds.), Methodology in Language Teaching An Anthology of Current Practice (pp.364367). Cambridge: Cambridge University Press.

[10] Wesche, M., \& Skehan, P. (2002). Communicative, task-based, and content-based language instruction. In R. B. Kaplan (Ed.), The Oxford handbook of applied linguistics (pp. 207-228). Oxford: Oxford University Press.

[11] Yumarnamto, M., \& Wibowo, S. (2008). Podcasts and Videocasts from Internet to improve Students' Listening Skills. Paper presented at Asia TEFL international

Trinh Thi Kieu Dinh received her bachelor's degree in English Language Teacher Education in 2013.

She received her master in Teaching English to Speakers of Other Languages (TESOL) in 2015. Her research interests are linguistics and teaching methods. 